\title{
Pengaruh Sales Growth, Current Ratio, firm Size dan Return on Assets Terhadap Struktur Modal pada Perusahaan Consumer Goods yang terdaftar di bursa Efek Indonesia tahun 2012-2016
}

\author{
Herna Sari Dewi \\ Universitas Prima Indonesia \\ hernasaridewi06@gmail.com

\section{Andri Tampubolon} \\ Universitas Prima Indonesia \\ andritampubolon50@gmail.com
}

\section{Angel Rika}

Universitas Prima Indonesia

angelrika996@gmail.com

\section{Thomas Handoko \\ Universitas Prima Indonesia \\ thomashandoko123@gmail.com}

\section{Hottua Samosir, S.Pd.,M.Si}

Universitas Prima Indonesia

Enda Noviyanti Simorangkir,S.E.,M.Si

Universitas Prima Indonesia

\begin{abstract}
Abstrak
Struktur modal adalah pendanaan permanen yang terdiri dari hutang jangka panjang, saham preferen, dan modal pemegang saham. Upaya penetapan struktur modal perlu mempertimbangkan dan memperhatikan berbagai variabel yang mempengaruhinya karena secara langsung keputusan struktur modal akan mempengaruhi kondisi dan nilai perusahaan serta menentukan kemampuan perusahaan untuk tetap bertahan dan berkembang. Pendekatan penelitian menggunakan pendekatan kuantitatif. Jenis penelitian menggunakan penelitian kuantitatif dan sifat penelitian adalah penelitian kausal. Teknik pengambilan sampel adalah purposive sampling dan didapat sampel sebanyak 25 perusahaan. Hasil penelitian menunjukkan secara parsial Sales Growth tidak berpengaruh signifikan terhadap struktur modal, Current Ratio dan Return On Assets berpengaruh negatif signifikan terhadap struktur modal, dan Firm Size berpengaruh positif signifikan terhadap struktur modal. Hasil penelitian menunjukkan secara simultan Sales Growth, Current Ratio, Firm Size, dan Return On Assets berpengaruh signifikan terhadap struktur modal pada perusahaan
\end{abstract}


Consumer Goods yang terdaftar di Bursa Efek Indonesia tahun 20122016.

Kata Kunci Sales Growth, Current Ratio, Firm Size, Return On Assets, Struktur Modal

\section{PENDAHULUAN}

Perusahaan consumer goods merupakan produsen barang-barang konsumsi yang menjadi kebutuhan utama bagi konsumen. Umumnya, perusahaan ini tidak terpengaruh kondisi ekonomi dan tangguh di tengah krisis karena produk-produk konsumsi merupakan kebutuhan primer manusia. Perubahan kondisi ekonomi tidak banyak mempengaruhi minat konsumen untuk membeli barang-barang dari perusahaan industri barang konsumsi. Tingkat kebutuhan yang stabil terhadap produk konsumsi dengan berbagai situasi global menunjukkan sifat defensif sektor konsumsi, terlebih lagi untuk wilayah Indonesia dimana target pasar barang konsumsi adalah manusia sehingga Indonesia yang dihuni oleh lebih dari 200.000.000 orang manusia pastinya memiliki tingkat kebutuhan yang tinggi juga.

Pengembangan perusahaan dalam upaya untuk mengantisipasi persaingan yang semakin ketat seperti sekarang ini akan selalu dilakukan baik perusahaan besar maupun perusahaan kecil. Upaya tersebut menjadi permasalahan tersendiri bagi perusahaan, karena menyangkut pemenuhan dana yang diperlukan. Sumber pendanaan yang didapat oleh suatu perusahaan dapat berasal dari internal maupun eksternal perusahaan. Dana internal adalah dana yang dibentuk atau dihasilkan sendiri dalam perusahaan yaitu laba yang ditahan dan akumulasi depresiasi. Dana eksternal adalah dana dari para kreditur dan pemilik, peserta atau pengambil bagian dalam perusahaan (Suweta \& Dewi, 2016).

Pertumbuhan penjualan merupakan kemampuan perusahaan untuk meningkatkan tujuan perusahaan dalam meningkatkan kinerja keuangan perusahaan. Saat pertumbuhan penjualan meningkat perusahaan akan mengambil utang agar dapat meningkatkan kapasitas produksi yang akan berdampak pada kenaikan penjualannya. Pertumbuhan penjualan termasuk salah satu faktor yang mempengaruhi struktur modal (Maryanti, 2017).

Current Ratio menunjukkan sejauh mana aktiva lancar menutupi kewajibankewajiban lancar. Semakin besar perbandingan aktiva lancar dengan utang lancar semakin tinggi kemampuan perusahaan menutupi kewajiban jangka pendeknya (Harahap, 2016:301). Semakin tinggi kemampuan perusahaan dalam mengembalikan kewajibankewajiban jangka pendeknya maka semakin likuid perusahaan tersebut sehingga kepercayaan dari kreditur meningkat dan mempermudah perusahaan memperoleh utang jangka panjangnya (Andika \& Fitria, 2016).

Besar kecilnya ukuran suatu perusahaan akan berpengaruh terhadap struktur modal, di mana semakin besar suatu perusahaan, maka semakin besar pula dana yang dibutuhkan perusahaan untuk melakukan investasinya. Hal ini dikarenakan perusahaan besar membutuhkan dana yang besar pula untuk menunjang operasionalnya dan salah satu alternatif pemenuhannya adalah dengan pendanaan eksternal (Nita Septiani \& Suaryana, 2018). 
Return On Assets digunakan untuk mengukur tingkat profitabilitas perusahaan. Return On Assets menunjukkan seberapa efisien perusahaan menggunakan asetnya untuk menghasilkan laba (Wira, 2011:72). Perusahaan dengan tingkat pengembalian yang tinggi atas investasi menggunakan utang yang relatif kecil karena tingkat pengembalian yang tinggi memungkinkan perusahaan untuk membiayai sebagian besar pendanaan internal. Dengan laba ditahan yang besar, perusahaan akan menggunakan laba ditahan sebelum memutuskan untuk menggunakan utang (Kartika, 2016).

Tabel 1. Data Keuangan Sales Growth, Current Ratio, Firm Size, Return On Assets dan Struktur Modal pada Perusahaan Consumer Goods yang Terdaftar di Bursa Efek Indonesia

Tahun 2012-2016 (disajikan dalam jutaan rupiah)

\begin{tabular}{|c|c|c|c|c|c|c|}
\hline $\begin{array}{c}\text { Kode } \\
\text { Emiten }\end{array}$ & Tahun & Penjualan & $\begin{array}{c}\text { Aset } \\
\text { Lancar }\end{array}$ & Total Aset & $\begin{array}{c}\text { Laba } \\
\text { Bersih }\end{array}$ & $\begin{array}{c}\text { Total } \\
\text { Hutang }\end{array}$ \\
\hline \multirow{4}{*}{ GGRM } & 2012 & 49.028 .696 & 29.954 .021 & 41.509 .325 & 4.068 .711 & 14.903 .612 \\
\cline { 2 - 7 } & 2013 & 55.436 .954 & 34.604 .461 & 50.770 .251 & 4.383 .932 & 21.353 .980 \\
\cline { 2 - 7 } & 2014 & 65.185 .850 & 38.532 .600 & 58.234 .278 & 5.432 .667 & 25.099 .875 \\
\cline { 2 - 7 } & $\mathbf{2 0 1 5}$ & $\mathbf{7 0 . 3 6 5 . 5 7 3}$ & 42.568 .431 & 63.505 .413 & 6.452 .834 & $\mathbf{2 5 . 4 9 7 . 5 0 4}$ \\
\cline { 2 - 7 } & $\mathbf{2 0 1 6}$ & $\mathbf{7 6 . 2 7 4 . 1 4 7}$ & 41.933 .173 & 62.951 .634 & 6.672 .682 & $\mathbf{2 3 . 3 8 7 . 4 0 6}$ \\
\hline \multirow{5}{*}{ AISA } & 2012 & 2.747 .623 & 1.544 .940 & 3.867 .576 & 253.664 & 1.834 .123 \\
\cline { 2 - 7 } & 2013 & 4.056 .735 & 2.445 .504 & 5.025 .778 & 346.728 & 2.666 .648 \\
\cline { 2 - 7 } & 2014 & 5.139 .974 & 3.977 .086 & 7.373 .868 & 377.903 & 3.787 .932 \\
\cline { 2 - 7 } & $\mathbf{2 0 1 5}$ & 6.010 .895 & $\mathbf{4 . 4 6 3 . 6 3 5}$ & 9.060 .980 & 373.750 & $\mathbf{5 . 0 9 4 . 0 7 3}$ \\
\cline { 2 - 7 } & $\mathbf{2 0 1 6}$ & 6.545 .680 & $\mathbf{5 . 9 4 9 . 1 6 4}$ & 9.254 .539 & 719.228 & $\mathbf{4 . 9 9 0 . 1 3 9}$ \\
\hline \multirow{5}{*}{ DLTA } & 2012 & 719.951 & 631.333 & 745.306 & 213.421 & 147.095 \\
\cline { 2 - 7 } & 2013 & 867.066 & 748.111 & 867.040 & 270.498 & 190.482 \\
\cline { 2 - 7 } & 2014 & 879.253 & 854.176 & 991.947 & 764.473 & 227.473 \\
\cline { 2 - 7 } & $\mathbf{2 0 1 5}$ & 699.506 & 902.006 & $\mathbf{1 . 0 3 8 . 3 2 1}$ & 192.045 & $\mathbf{1 8 8 . 7 0 0}$ \\
\cline { 2 - 7 } & $\mathbf{2 0 1 6}$ & 774.968 & 1.048 .133 & $\mathbf{1 . 1 9 7 . 7 9 6}$ & 254.509 & $\mathbf{1 8 5 . 4 2 2}$ \\
\hline \multirow{5}{*}{ KLBF } & 2012 & 13.636 .405 & 6.441 .710 & 9.417 .957 & 1.775 .098 & 2.046 .313 \\
\cline { 2 - 7 } & 2013 & 16.002 .131 & 7.497 .319 & 11.315 .061 & 1.970 .452 & 2.815 .103 \\
\cline { 2 - 7 } & 2014 & 17.368 .532 & 8.120 .805 & 11.425 .032 & 2.121 .090 & 2.607 .556 \\
\cline { 2 - 7 } & $\mathbf{2 0 1 5}$ & 17.887 .464 & 8.745 .465 & 13.696 .417 & $\mathbf{2 . 0 5 7 . 6 9 4}$ & $\mathbf{2 . 7 5 8 . 1 3 1}$ \\
\cline { 2 - 7 } & $\mathbf{2 0 1 6}$ & 19.374 .230 & 9.572 .529 & 15.226 .009 & $\mathbf{2 . 3 5 0 . 8 8 4}$ & $\mathbf{2 . 7 6 2 . 1 6 2}$ \\
\hline
\end{tabular}

Sumber :www.idx.co.id

1. Berdasarkan data keuangan PT. Gudang Garam Tbk, penjualan pada tahun 2015 dan penjualan pada tahun 2016 mengalami kenaikan 8\%, sedangkan total hutang pada tahun 2015 dan total hutang pada tahun 2016 mengalami penurunan sebesar $-8 \%$. 
2. Berdasarkan data keuangan PT. Tiga Pilar Sejahtera Food Tbk, aset lancar pada tahun 2015 dan aset lancar pada tahun 2016 mengalami kenaikan sebesar 33\%, sedangkan total hutang pada tahun 2015 dan total hutang pada tahun 2016 mengalami penurunan sebesar $-2 \%$.

3. Berdasarkan data keuangan PT. Delta Djakarta Tbk, total aset pada tahun 2015 dan total aset pada tahun 2016 mengalami kenaikan sebesar 15\%, sedangkan total hutang pada tahun 2015 dan total hutang pada tahun 2016 mengalami penurunan sebesar $-2 \%$.

4. Berdasarkan data keuangan PT. Kalbe Farma Tbk, laba bersih pada tahun 2015 dan laba bersih pada tahun 2016 mengalami kenaikan sebesar 14\%, sedangkan total hutang pada tahun 2015 dan total hutang pada tahun 2016 mengalami kenaikan sebesar $0,15 \%$.

Tujuan dari penelitian ini adalah :

1. Untuk menguji dan menganalisis pengaruh Sales Growth secara parsial terhadap struktur modal pada perusahaan Consumer Goods yang terdaftar di Bursa Efek Indonesia tahun 2012-2016.

2. Untuk menguji dan menganalisis pengaruh Current Ratio secara parsial terhadap struktur modal pada perusahaan Consumer Goods yang terdaftar di Bursa Efek Indonesia tahun 2012-2016.

3. Untuk menguji dan menganalisis pengaruh Firm Size secara parsial terhadap struktur modal pada perusahaan Consumer Goods yang terdaftar di Bursa Efek Indonesia tahun 2012-2016.

4. Untuk menguji dan menganalisis pengaruh Return On Assets secara parsial terhadap struktur modal pada perusahaan Consumer Goods yang terdaftar di Bursa Efek Indonesia tahun 2012-2016.

5. Untuk menguji dan menganalisis pengaruh Sales Growth, Current Ratio, Firm Size dan Return On Assets secara simultan terhadap struktur modal pada perusahaan Consumer Goods yang terdaftar di Bursa Efek Indonesia tahun 20122016.

\section{LANDASAN TEORI}

\section{Sales Growth}

Menurut Harahap (2016:310), pertumbuhan penjualan menunjukkan persentasi kenaikan penjualan tahun ini dibanding dengan tahun laluyang dapat dilihat pada laporan labarugi perusahaan. Semakin tinggi semakin baik.

$$
\text { Sales Growth }=\frac{\text { Penjualan Tahun Ini }- \text { Penjualan Tahun Lalu }}{\text { Penjualan Tahun Lalu }}
$$




\section{Current Ratio}

Menurut Syahyunan (2013:93), current ratio atau rasio lancar digunakan untuk menghitung kemampuan perusahaan dalam membayar kewajiban jangka pendek dengan aset lancar yang tersedia.

$$
\text { Current Ratio }=\frac{\text { Aset Lancar }}{\text { Utang Lancar }}
$$

\section{Firm Size}

Menurut Mulyawan (2015:247), firm size mengindikasikan bahwa semakin besar suatu perusahaan, semakin besar pula tingkat utangnya. Perusahaan kecil atau masih baru kemungkinan memiliki kas inflows yang rendah dalam menghadapi peluang investasi yang menguntungkan, tidakmempunyai akses untuk masuk pada pasar modal reguler sehingga tidak mengajak pihak luar (outsiders) sebagai partner atau rekan kerja.

\section{Firm Size $=$ Logaritme Natural asset}

\section{Return On Assets}

Menurut Hery (2015:228), semakin tinggi hasil pengembalian atas aset berarti semakin tinggi pula jumlah laba bersih yang dihasilkan dari setiap rupiah dana yang tertanam dalam total aset. Sebaliknya, semakin rendah hasil pengembalian aset berarti semakin rendah pula jumlah laba bersih yang dihasilkan dari setiap rupiah dana yang tertanam dalam total aset.

$$
\text { Return On Assets }=\frac{\text { Laba Bersih }}{\text { Total Aset }}
$$

\section{Struktur Modal}

Menurut Rodoni dan Ali (2014:129), struktur modal adalah proporsi dalam menentukan pemenuhan kebutuhan belanja perusahaan, dimana dana yang diperoleh menggunakan kombinasi atau panduan sumber yang berasal dari dana jangka panjang yang terdiri dari dua sumber utama yakni yang berasal dari dalam dan luar perusahaan.

$$
\text { Debt to Equity Ratio }=\frac{\text { Total Utang }}{\text { Total Modal }}
$$

\section{Sales Growth Terhadap Struktur Modal}

Menurut Sudana (2011:162), perusahaan yang tingkat pertumbuhan penjualannya relatif tinggi dimungkinkan untuk dibelanjai dengan menggunakan utang yang lebih besar dibandingkan dengan perusahaan yang pertumbuhan penjualannya rendah, karena keuntungan yang diperoleh dari peningkatan penjualan tersebut diharapkan masih bisa menutup biaya bunga utang. 
H1. Sales growth berpengaruh terhadap struktur modal.

\section{Current Ratio Terhadap Struktur Modal}

Menurut Sunyoto (2013:14), apabila korporasi itu tidak cukup likuiditasnya maka korporasi dapat meminjam kepada bank melalui pinjaman jangka pendek, cerukan dan anjak piutang.

$\mathbf{H}_{2}$.Current ratio berpengaruh terhadap struktur modal.

\section{Firm Size Terhadap Struktur Modal}

Menurut Sitanggang (2013:76), ukuran perusahaan dengan kapitalisasi pasar atau penjualan yang besar menunjukkan prestasi perusahaan. Perusahaan yang besar akan lebih mudah mendapatkan akses ke sumber dana untuk memperoleh tambahan modal dengan utang.

H3. Firm size berpengaruh terhadap struktur modal.

\section{Return On Assets Terhadap Struktur Modal}

Menurut Sinaga (2014:353), tingkat pengembalian yang tinggi memungkinkan untuk membiayai sebagian besar kebutuhan pendanaan dengan dana yang dihasilkan secara internal. Hal ini menunjukkan bahwa profitabilitas berpengaruh terhadap struktur modal. Semakin tinggi keuntungan yang diperoleh berarti semakin rendah utang.

H4. Return on assets berpengaruh terhadap struktur modal.

\section{III.METODOLOGI PENELITIAN}

\section{Metode Penelitian}

Penelitian ini menggunakan pendekatan kuantitatif, yaitu metode penelitian yang digunakan untuk meneliti pada populasi atau sampel tertentu. Sifat penelitian ini adalah hubungan kausal, yaitu hubungan yang bersifat sebab akibat antara variabel independen (variabel yang mempengaruhi) dan variabel dependen (variabel yang dipengaruhi). Metode pengumpulan data dalam penelitian ini dilakukan dengan studi dokumentasi yang merupakan teknik pengumpulan dengan cara mencatat, mengumpulkan, dan mempelajari data-data perusahaan terkait masalah yang sedang diteliti.Jenis data yang digunakan dalam penelitian ini adalah data sekunder, yaitu berupa laporan keuangan perusahaan consumer goods yang terdaftar di Bursa Efek Indonesia tahun 2012-2016.

\section{Populasi dan Sampel}

Populasi yang digunakan dalam penelitian ini adalah 37 laporan keuangan perusahaan consumer goods yang terdaftar di Bursa Efek Indonesia tahun 2012-2016. Penelitian ini menggunakan teknik purposive sampling, yaitu teknik penentuan sampel dengan pertimbangan tertentu. Jumlah sampel yang memenuhi kriteria pemilihan sampel sebanyak 25 perusahaan dengan pengamatan 5 tahun sehingga sampel penelitian didapatkan sebanyak 125 sampel untuk data penelitan. Adapun kriteria-kriteria dalam pemilihan sampel yaitu:

1. Perusahaan consumer goodsyang terdaftar di Bursa Efek Indonesia tahun 20122016. 
2. Perusahaan consumer goods yang mempublikasikan laporan keuangan lengkap secara berturut-turut selama tahun 2012-2016.

3. Perusahaan consumer goods yang memiliki laba pada tahun 2012-2016.

\section{Model Analisis Data Penelitian}

Model analisis dalam penelitian ini adalah model regresi linier berganda, digunakan untuk menganalisis pengaruh variabel independen terhadap variabel dependen. Pengujian hipotesis dalam penelitian ini dilakukan dengan cara pengujian hipotesis secara simultan (uji F) dan pengujian hipotesis secara parsial (uji t).

\section{HASIL PENELITIAN DAN PEMBAHASAN}

\section{Hasil Uji Asumsi Klasik}

\subsection{Uji Normalitas}

Uji normalitas digunakan untuk menguji apakah data residual sudahberdistribusi secara normal atau tidak normal. Penelitian ini menggunakan uji normalitas dengan melihat Grafik Histogram, Probability Plots dan Kolmogorov Smirnov Test.

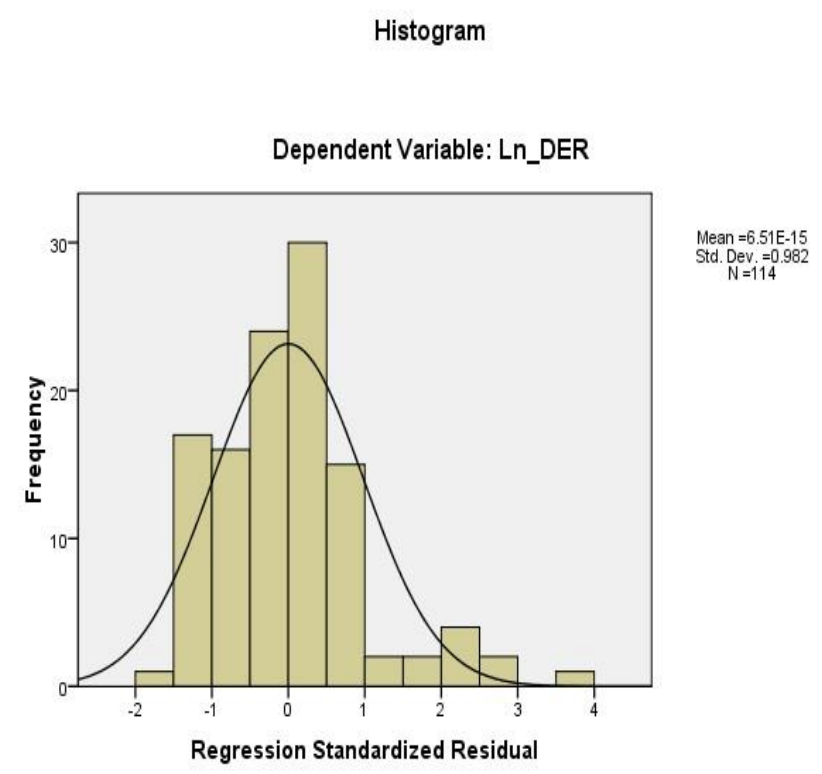

\section{Gambar IV.1 Hasil Uji Normalitas - Grafik Histogram}

Sumber : Hasil Pengolahan Data

Berdasarkan Gambar IV.1 menunjukan bahwa arah grafik histogram memberikan pola distribusi yang baik dengan adanya data yang mengikuti kurva berbentuk lonceng. Dengan demikian, hasil ini memenuhi syarat karena data dalam model regresi terdistribusi normal. 


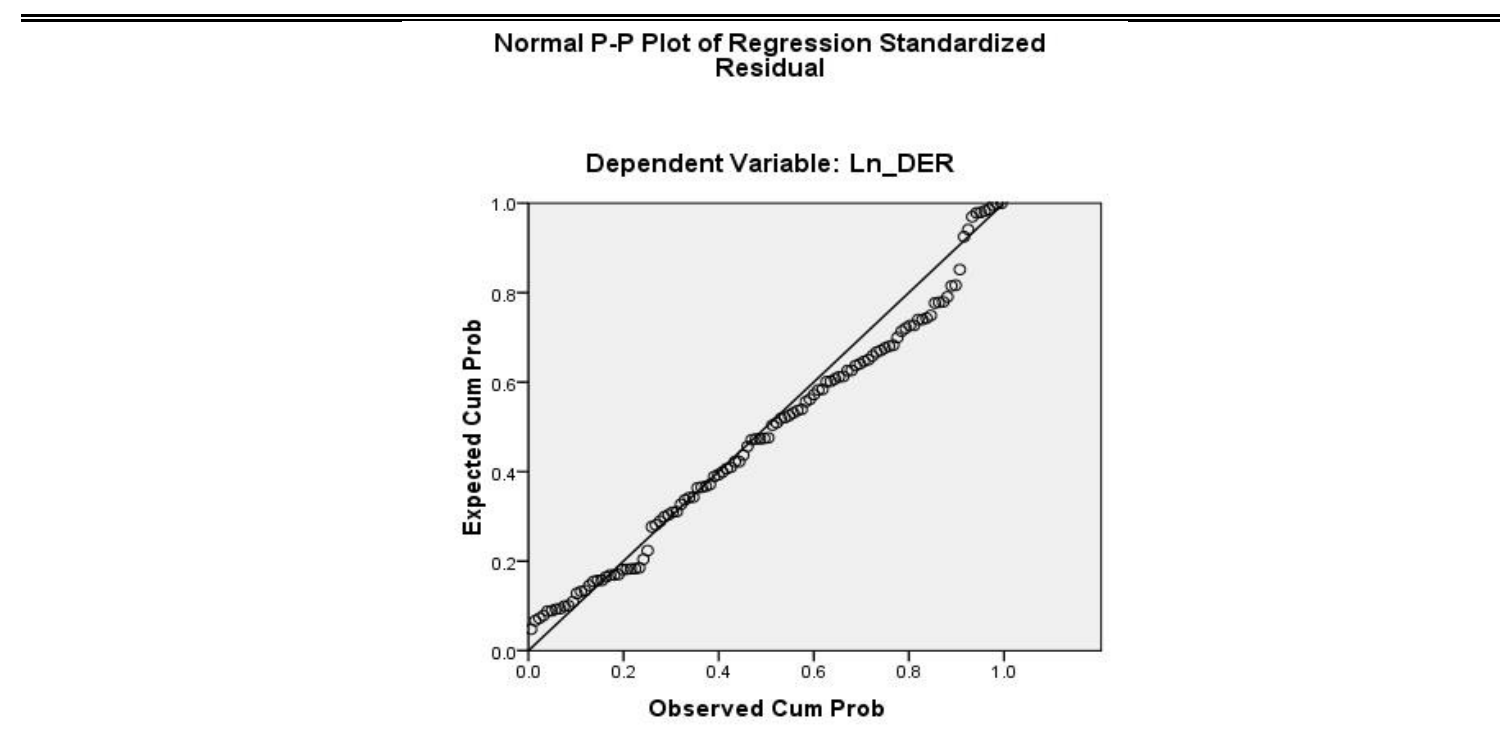

Gambar IV.2 Hasil Uji Normalitas - Probability Plots

Sumber : Hasil Pengolahan Data

Berdasarkan Gambar IV.2 menunjukkan bahwa pola data dimana titik-titik menyebar disekitar garis diagonal dan mengikuti arah garis diagonal. Dengan demikian, hasil ini memenuhi syarat karena data dalam model regresi terdistribusi normal.

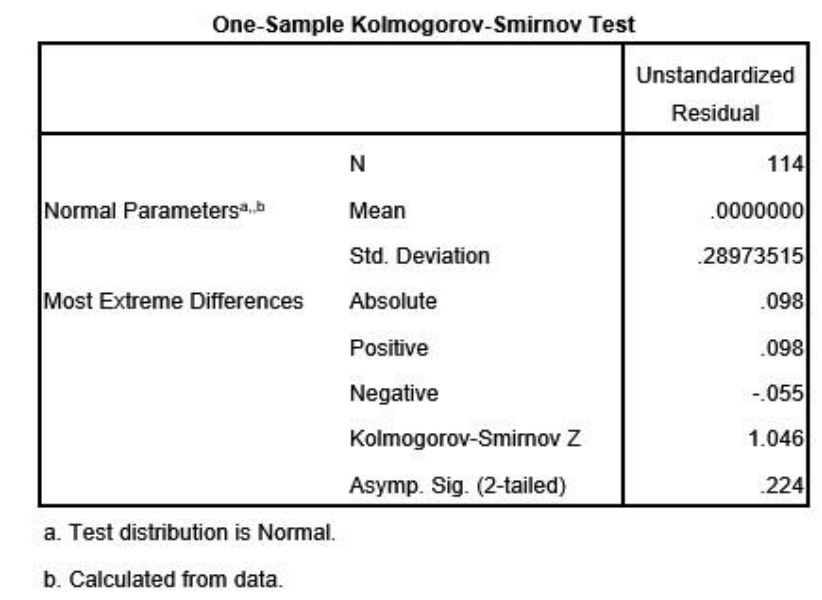

\section{Tabel IV.1 Hasil Uji Normalitas - Kolmogorov Smirnov}

Sumber : Hasil Pengolahan Data

Berdasarkan Tabel IV.1 menunjukkan nilai Asymp. Sig. (2-tailed) sebesar 0,224 lebih besar dari 0,05. Dengan demikian, hasil ini memenuhi syarat karena data dalam model regresi terdistribusi normal. 


\subsection{Uji Multikolinieritas}

Uji multikolinieritas dilakukan untuk melihat ada tidaknya hubungan linier diantara variabel independen dalam model regresi. Nilai cut off yang umum dipakai untuk menunjukan adanya multikolinieritas adalah nilai Tolerance $\leq 0,10$ dan dengan nilai VIF $\geq 10$.

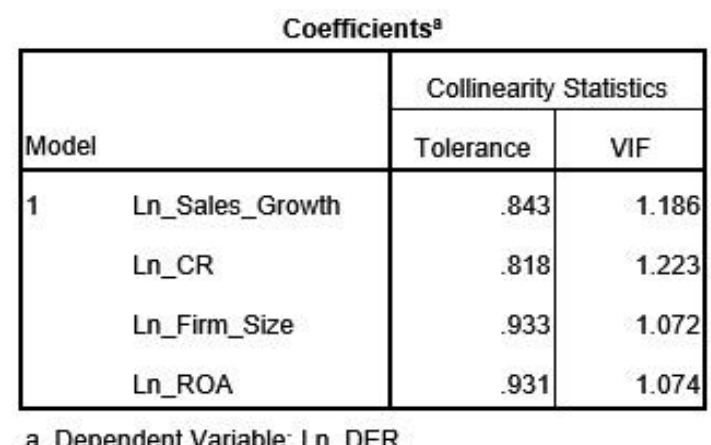

\section{Tabel IV.2 Hasil Uji Multikolinieritas}

Sumber : Hasil Pengolahan Data

Berdasarkan Tabel IV.2 menunjukkan nilai tolerance dari variabel independen Sales Growth bernilai 0,843, Current Ratio bernilai 0,818, Firm Size bernilai 0,933, dan Return On Assets bernilai 0,931 berada di atas 0,10. Sedangkan nilai Variance Inflation Factor (VIF) dari variabel independen Sales Growth bernilai 1,186, Current Ratio bernilai 1,223, Firm Size bernilai 1,072, dan Return On Assets bernilai 1,074 berada di bawah 10. Dengan demikian, model penelitian ini dapat dikatakan tidak terjadi / bebas dari multikolinieritas.

\subsection{Uji Autokorelasi}

Uji autokorelasi digunakan untuk menguji apakah dalam sebuah model regresi linear ada korelasi antara kesalahan pengganggu pada periode $t$ dengan kesalahan pengganggu pada periode t-1 (periode sebelumnya). Salah satu ukuran dalam menentukan ada tidaknya masalah autokorelasi dengan uji Durbin Watson (DW-test).

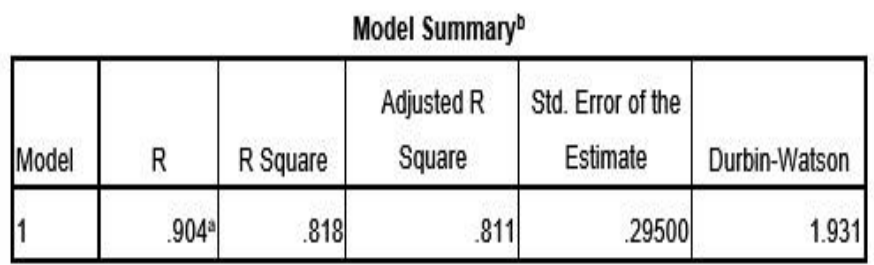

a. Predictors: (Constant), Ln_ROA, Ln_Sales_Growth, Ln_Firm_Size, Ln_CR

b. Dependent Variable: Ln_DER

Tabel IV.3 Hasil Uji Autokorelasi - Durbin Watson 
Sumber : Hasil Pengolahan Data

Berdasarkan Tabel IV.3 menunjukkan besarnya nilai durbin-watson sebesar 1,931. Hasil pengujian menurut tabel durbin-watson nilai du sebesar 1,7745 maka hasil pengujian menunjukkan $1,7745<1,931<2,2255$. Dengan demikian, dapat disimpulkan bahwa model persamaan regresi tidak terjadi autokorelasi baik positif maupun negatif karena nilai durbin-watson 1,931 berada diatas 1,7745 dan dibawah 2,2255.

\subsection{Uji Heteroskedastisitas}

Uji heteroskedastisitas berguna untuk menguji apakah dalam model regresi terjadi ketidaksamaan variance dari residual satu pengamatan ke pengamatan yang lain. Model regresi yang baik adalah tidak terjadi heteroskedastisitas. Pada penelitian ini, cara mendeteksi ada tidaknya gejala heteroskedastisitas yaitu menggunakan grafik scatterplot dan uji white.

Scatterplot

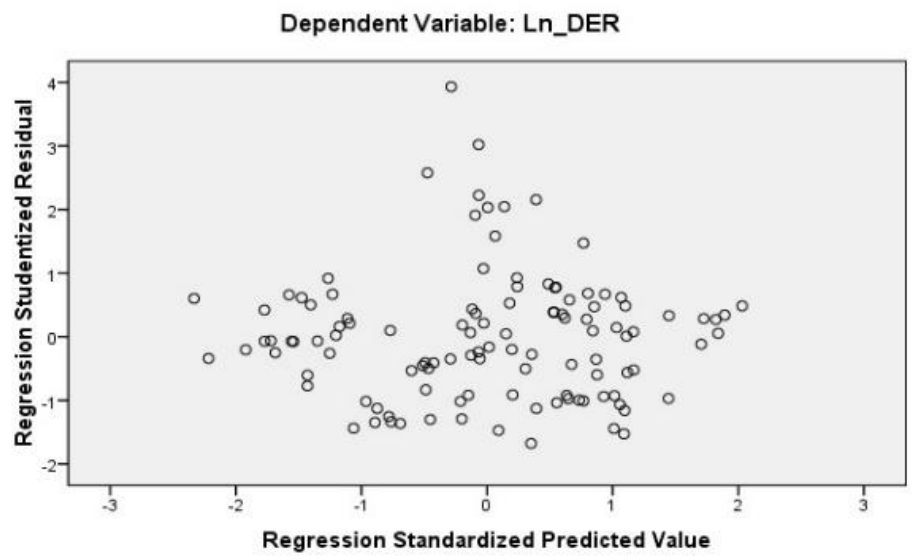

Gambar IV.3 Hasil Uji Heteroskedastisitas - Grafik Scatterplot

Sumber : Hasil Pengolahan Data

Berdasarkan Gambar IV.3 menunjukan bahwa penyebaran titik-titik menyebar secara acak, serta tersebar baik di atas maupun di bawah angka nol (0) pada sumbu Y. Dengan demikian, dapat dikatakan data tidak terjadi heteroskedastisitas pada model regresi. 


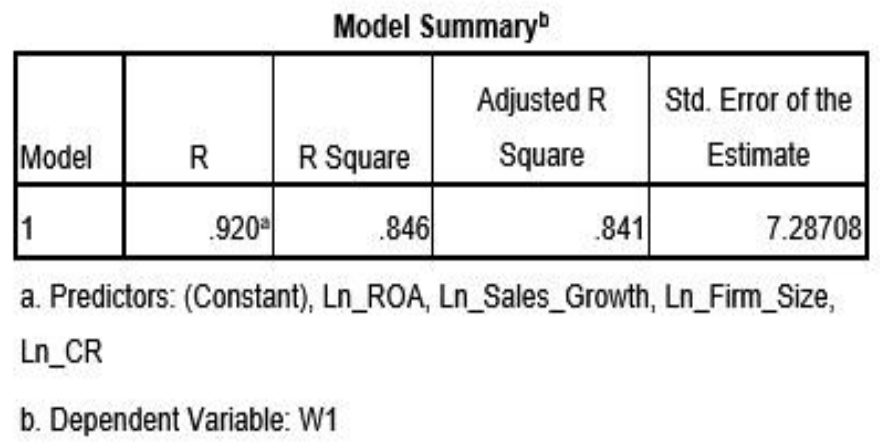

\section{Tabel IV.4 Hasil Uji Heteroskedastisitas - Uji White}

Sumber : Hasil Pengolahan Data

Berdasarkan Tabel IV.4 menunjukkan besarnya nilai chi square hitung adalah (n.R2 $=125 \times 0,846=105,75)$. Sedangkan besarnya chi square tabel pada tingkat signifikan 0,05 dan derajat kebebasan sampel $(\mathrm{N})$ sebesar 125 adalah 152,094 dengan demikian dapat disimpulkan chi square hitung < chi square tabel $(105,75<152,094)$ sehingga tidak terjadi heteroskedastisitas.

\section{Hasil Analisis Data Penelitian}

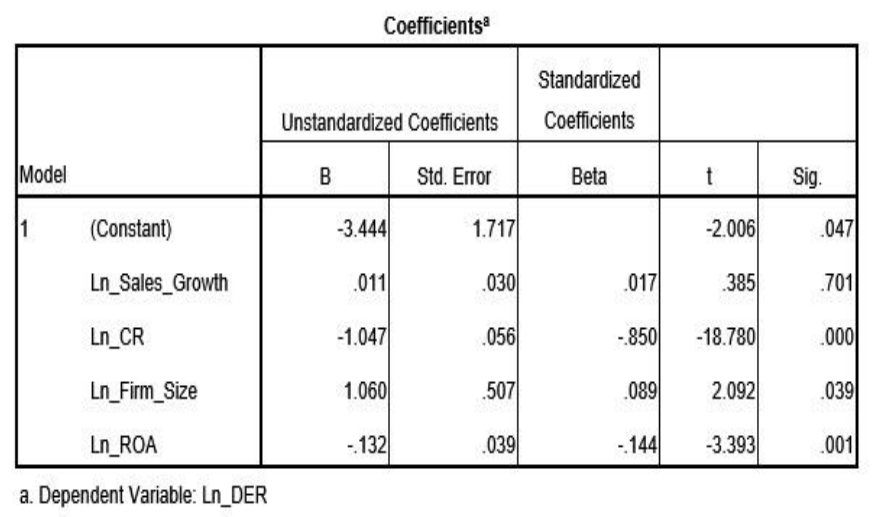

\section{Tabel IV.5 Hasil Analisis Regresi Linear Berganda}

Sumber : Hasil Pengolahan Data

Berdasarkan Tabel IV.5 diperoleh hasil analisis regresi linear berganda, yaitu : $Y=-3,444+0,011 X_{1}-1,047 X_{2}+1,060 X_{3}-0,132 X_{4}$

Makna dari persamaan regresi linear berganda diatas adalah :

1. Nilaikonstanta sebesar -3,444 menyatakan bahwa jika Sales Growth, Current Ratio, Firm Size, dan Return On Assets bernilai nol atau konstan maka nilai struktur modal sebesar $-3,444$. 
2. Nilai koefisien regresi Sales Growth sebesar 0,011 menyatakan bahwa setiap kenaikan Sales Growth sebesar 1 satuan menyebabkan struktur modal mengalami kenaikan sebesar 0,011 .

3. Nilai koefisien regresi Current Ratio sebesar -1,047 menyatakan bahwa setiap kenaikan Current Ratio sebesar 1 satuan menyebabkan struktur modal mengalami penurunan sebesar $-1,047$.

4. Nilaikoefisien regresi Firm Size sebesar 1,060 menyatakan bahwa setiap kenaikan Firm Size sebesar 1 satuan menyebabkan struktur modal mengalami kenaikan sebesar 1,060 .

5. Nilai koefisien regresi Return On Assets sebesar -0,132 menyatakan bahwa setiap kenaikan Return On Assets sebesar 1 satuan menyebabkan struktur modal mengalami penurunan sebesar -0,132.

\begin{tabular}{|l|r|r|r|r|}
\hline & \multicolumn{1}{|c|}{ Model Summary } \\
\hline Model & \multicolumn{1}{c|}{ R } & R Square & $\begin{array}{c}\text { Adjusted R } \\
\text { Square }\end{array}$ & $\begin{array}{c}\text { Std. Error of the } \\
\text { Estimate }\end{array}$ \\
\hline 1 & $.904^{2}$ & .818 & .811 & .29500 \\
\hline
\end{tabular}
a. Predictors: (Constant), Ln_ROA, Ln_Sales_Growth, Ln_Firm_Size,
Ln_CR
b. Dependent Variable: Ln_DER

\section{Tabel IV.6 Hasil Pengujian Koefisien Determinasi $\left(\mathbf{R}^{2}\right)$}

Sumber : Hasil Pengolahan Data

Berdasarkan Tabel IV.6 diperoleh nilai Adjusted R Square (R2) koefisien determinasi sebesar 0,818 atau sama dengan $81,8 \%$, artinya variasi variabel terikat struktur modal yang dapat dijelaskan oleh variabel bebas Sales Growth, Current Ratio, Firm Size, dan Return On Assets adalah sebesar 81,8\%, sisanya 18,2\% dijelaskan oleh variabel bebas lain yang tidak diteliti dalam penelitian ini.

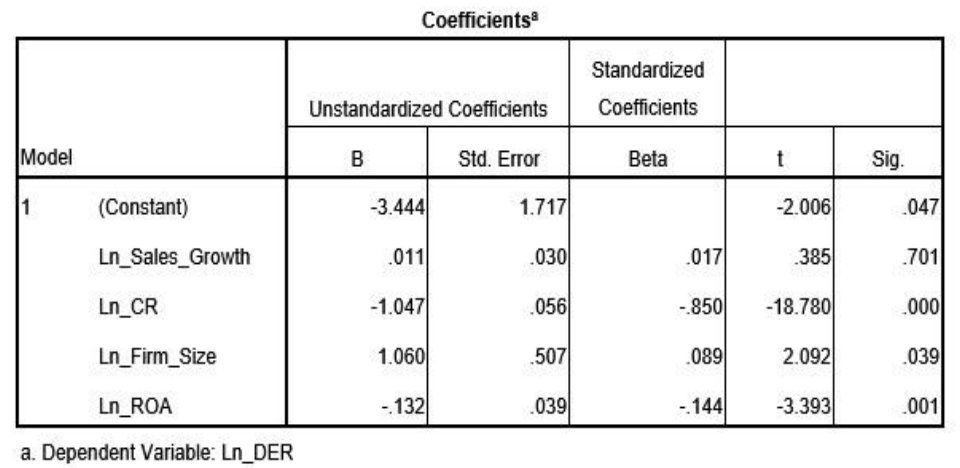

Tabel IV.7 Hasil Pengujian Secara Parsial (Uji t) 
Sumber : Hasil Pengolahan Data

1. Sales Growth diperoleh $\mathrm{t}_{\text {hitung }}$ sebesar 0,385 dan $\mathrm{t}_{\text {tabel }}$ sebesar 1,980 maka $-\mathrm{t}_{\text {tabel }} \leq \mathrm{t}_{\text {hitung }}$ $\leq \mathrm{t}_{\text {tabel }}(-1,980 \leq 0,385 \leq 1,980)$ dengan nilai signifikan $0,701>0,05$. Maka $\mathrm{H}_{0}$ diterima dan Ha ditolak, artinya Sales Growth secara parsial tidak berpengaruh dan tidak signifikan terhadap struktur modal pada perusahaan consumer goods yang terdaftar di Bursa Efek Indonesia tahun 2012-2016.

2. Current Ratio diperoleh thitung sebesar $-18,780$ dan ttabel sebesar 1,980 maka thitung < $-t_{\text {tabel }}(-18,780<-1,980)$ dengan nilai signifikan $0,000<0,05$. Maka $\mathrm{H}_{0}$ ditolak dan Ha diterima, artinya Current Ratio secara parsial berpengaruh negatif dan signifikan terhadap struktur modal pada perusahaan consumer goods yang terdaftar di Bursa Efek Indonesia tahun 2012-2016.

3. Firm Size diperoleh thitung sebesar 2,092 dan $t_{\text {tabel }}$ sebesar 1,980 maka $t_{\text {hitung }}>t_{\text {tabel }}$ $(2,092>1,980)$ dengan nilai signifikan $0,039<0,05$. Maka $\mathrm{H}_{0}$ ditolak dan $\mathrm{Ha}$ diterima, artinya Firm Size secara parsial berpengaruh positif dan signifikan terhadap struktur modal pada perusahaan consumer goods yang terdaftar di Bursa Efek Indonesia tahun 2012-2016.

4. Return On Assets diperoleh $t_{\text {hitung }}$ sebesar $-3,393$ dan $t_{\text {tabel }}$ sebesar 1,980 maka $t_{\text {hitung }}<$ $-\mathrm{t}_{\text {tabel }} \mathrm{l}(-3,393<-1,980)$ dengan nilai signifikan $0,001<0,05$. Maka $\mathrm{H}_{0}$ ditolak dan Ha diterima, artinya Return On Assets secara parsial berpengaruh negatif dan signifikan terhadap struktur modal pada perusahaan consumer goods yang terdaftar di Bursa Efek Indonesia tahun 2012-2016.

\begin{tabular}{|c|c|c|c|c|c|c|}
\hline \multicolumn{7}{|c|}{ ANOVA ${ }^{b}$} \\
\hline \multicolumn{2}{|c|}{ Model } & Sum of Squares & df & Mean Square & $\mathrm{F}$ & Sig. \\
\hline 1 & Regression & 42.499 & 4 & 10.625 & 122.087 & $.000^{\circ}$ \\
\hline & Residual & 9.486 & 109 & .087 & & \\
\hline & Total & 51.985 & 113 & & & \\
\hline
\end{tabular}

\section{Tabel IV.8 Hasil Pengujian Secara Simultan (Uji F)}

Sumber : Hasil Pengolahan Data

Berdasarkan Tabel IV.8 diperoleh $F_{\text {hitung }}(122,087)>F_{\text {tabel }}(2,45)$ dengan tingkat signifikansi $0,000<0,05$. Maka Ha diterima dan $\mathrm{H}_{0}$ ditolak artinya Sales Growth, Current Ratio, Firm Size, dan Return On Assets secara simultan berpengaruh terhadap struktur modal pada perusahaan consumer goods yang terdaftar di Bursa Efek Indonesia tahun 2012-2016.

\section{Pembahasan}

Hasil penelitian pengaruh Sales Growth terhadap struktur modal diperoleh nilai - $t_{\text {tabel }}$ $\leq t_{\text {hitung }} \leq \mathrm{t}_{\text {tabel }}(-1,980 \leq 0,385 \leq 1,980)$ dengan nilai signifikan $0,701>0,05$ sehingga Sales Growth tidak berpengaruh dan tidak signifikan terhadap struktur modal pada 
$\overline{\text { perusahaan consumer goods yang terdaftar di Bursa Efek Indonesia tahun 2012-2016. }}$ Pertumbuhan penjualan yang tinggi atau stabil saling berkaitan dengan keuntungan perusahaan. Tingkat pertumbuhan penjualan yang tinggi atau stabil dapat berpengaruh terhadap keuntungan perusahaan sehingga menjadi petimbangan perusahaan dalam menentukan struktur modal, hal tersebut berpengaruh terhadap hutang yang dimiliki perusahaan, perusahaan dapat memenuhi sebagian kebutuhan dengan keuntungan perusahaan (Siti Nurlaela, 2017). Hal ini juga dapat disebabkan penjualan barang dilakukan dengan cara penjualan kredit, yaitu dalam bentuk piutang sehingga kreditur tidak mempertimbangkan pertumbuhan penjualan perusahaan dalam memberikan kredit. Hasil penelitian ini tidak sejalan dengan hasil penelitian yang dilakukan oleh Suweta dan Dewi (2016) yang menyatakan Sales Growth berpengaruh positif signifikan terhadap struktur modal, tetapi sejalan dengan hasil penelitian yang dilakukan oleh Khariry dan Yusniar (2016) yang menyatakan bahwa Sales Growth tidak berpengaruh signifikan terhadap struktur modal.

Hasil penelitian pengaruh Current Ratio terhadap struktur modal diperoleh nilai thitung $<-t_{\text {tabel }}(-18,780<-1,980)$ dengan nilai signifikan $0,000<0,05$ sehingga Current Ratio secara parsial berpengaruh negatif dan signifikan terhadap struktur modal pada perusahaan consumer goods yang terdaftar di Bursa Efek Indonesia tahun 2012-2016. Perusahaan yang kurang likuid merupakan sinyal negatif bagi para kreditur untuk memberikan pinjaman dana. Jika semakin besar likuiditas maka semakin besar pula struktur modal dan jika semakin kecil likuiditas maka semakin kecil pula struktur modal (Andika \& Fitria, 2016). Penelitian ini sejalan dengan hasil penelitian yang dilakukan oleh Watung dan Saerang (2016) yang menyatakan bahwa Current Ratio berpengaruh negatif dan signifikan terhadap struktur modal.

Hasil penelitian pengaruh Firm Size terhadap struktur modal diperoleh nilai $t_{\text {hitung }}>$ $\mathrm{t}_{\text {tabel }}(2,092>1,980)$ dengan nilai signifikan $0,039<0,05$ sehingga Firm Size secara parsial berpengaruh positif dan signifikan terhadap struktur modal pada perusahaan consumer goods yang terdaftar di Bursa Efek Indonesia tahun 2012-2016. Perusahaan besar memiliki kemudahan akses sehingga fleksibilitas perusahaan besar juga lebih besar. Pihak kreditur atau pemberi hutang tentunya lebih menyukai untuk memberikan kredit kepada perusahaan besar sehingga perusahaan yang besar mempunyai kesempatan yang lebih luas dan mudah memperoleh kredit (Elsa Dwi Putri Fakultas Ekonomi Universitas Negeri Padang J1 Hamka Kampus Air Tawar Padang, 2012). Penelitian ini sejalan dengan hasil penelitian yang dilakukan oleh Riyadi (2014) yang menyatakan bahwa Firm Size berpengaruh positif dan signifikan terhadap struktur modal.

Hasil penelitian pengaruh Return On Assets terhadap struktur modal diperoleh nilai $t_{\text {hitung }}<-t_{\text {tabel }}(-3,393<-1,980)$ dengan nilai signifikan $0,001<0,05$ sehingga Return On Assets secara parsial berpengaruh negatif dan signifikan terhadap struktur modal pada perusahaan consumer goods yang terdaftar di Bursa Efek Indonesia tahun 2012-2016. Perusahaan yang memiliki profitabilitas tinggi berarti memiliki laba ditahan yang tinggi yang merupakan sumber dana internal perusahaan. Sehingga perusahaan dapat menggunakan laba ditahan tersebut untuk penambahan modalnya. Hal ini membuat perusahaan dapat mengurangi jumlah struktur modalnya (Damayanti, 2013). Penelitian ini sejalan dengan hasil penelitian yang dilakukan oleh Andika dan Fitria (2016) yang menyatakan bahwa Return On Assets berpengaruh negatif dan signifikan terhadap struktur modal. 


\section{KESIMPULAN}

Kesimpulan dari hasil penelitian ini adalah Sales Growth secara parsial tidak berpengaruh dan tidak signifikan terhadap struktur modal, Current Ratio secara parsial berpengaruh negatif dan signifikan terhadap struktur modal, Firm Size secara parsial berpengaruh positif dan signifikan terhadap struktur modal, dan Return On Assets secara parsial berpengaruh negatif dan signifikan terhadap struktur modal. Pengujian simultan Sales Growth, Current Ratio, Firm Size, dan Return On Assets secara keseluruhan berpengaruh terhadap struktur modal pada perusahaan Consumer Goods yang terdaftar di Bursa Efek Indonesia tahun 2012-2016.

\section{UCAPAN TERIMA KASIH}

Penulis mengucapkan banyak terima kasih kepada pihak Jesya (Jurnal Ekonomi \& Ekonomi Syariah) yang telah mengizinkan penulis untuk mempublikasikan jurnal ini.

\section{DAFTAR PUSTAKA}

Andika, A. P., \& Fitria, A. (2016). Pengaruh Struktur Aktiva, Ukuran perusahaan, Profitabilitas, dan Risiko Bisnis terhadap Struktur Modal. Jurnal Ilmu Dan Riset Akuntansi, 5(9), 1-19.

Damayanti. (2013). Pengaruh Struktur Aktiva, Ukuran Perusahaan, Peluang Bertumbuh dan Profitablitas terhadap Struktur Modal. Jurnal Perspektif Bisnis, 1(1), 17-32.

Elsa Dwi Putri Fakultas Ekonomi Universitas Negeri Padang Jl Hamka Kampus Air Tawar Padang, M. (2012). Pengaruh Profitabilitas, Struktur Aktiva dan Ukuran Perusahaan terhadap Struktur Modal pada Perusahaan Manufaktur Sektor Industri Makanan dan Minuman yang Terdaftar di Bursa Efek Indonesia (BEI). Jurnal Manajemen, 01(01), 1-10.

Harahap, Sofyan Safri. 2016. Analisis Kritis Atas Laporan Keuangan. Jakarta : PT RajaGrafindo Persada.

Hery. 2015. Analisis Laporan Keuangan Pendekatan Rasio Keuangan. Yogyakarta: CAPS.

Kartika, A. (2016). Pengaruh profitabilitas, struktur aset, pertumbuhan penjualan dan ukuran perusahaan terhadap struktur modal perusahaan manufaktur di Bursa Efek Indonesia. Jurnal AMIK JTC \INFOKAM, 12(1), 49-58.

Khariry, M., \& Yusniar, Meina, W. (2016). Faktor-Faktor Yang Mempengaruhi Struktur Modal (Studi Kasus Pada Perusahaan Manufaktur Yang Terdaftar Di Bursa Efek Indonesia). Efektif Jurnal Bisnis Dan Ekonomi, 4(2), 113-125.

Maryanti, E. (2017). ANALISIS PROFITABILITAS, PERTUMBUHAN PERUSAHAAN, PERTUMBUHAN PENJUALAN DAN STRUKTUR AKTIVA TERHADAP 
STRUKTUR MODAL PADA PERUSAHAAN SEKTOR INDUSTRI BARANG KONSUMSI YANG TERDAFTAR DI BURSA EFEK INDONESIA (Studi Empiris Pada Perusahaan Manufaktur yang Terdaf. Riset Akuntansi Dan Keuangan Indonesia, 1(2), 143.

Mulyawan, Setia. 2015. Manajemen Keuangan. Cetakan 1. Bandung : Pustaka Setia.

Nita Septiani, N. P., \& Suaryana, I. G. N. A. (2018). Pengaruh Profitabilitas, Ukuran Perusahaan, Struktur Aset, Risiko Bisnis dan Likuiditas pada Struktur Modal. EJurnal Akuntansi, 22, 1682.

Riyadi, N. P. (2014). Pengaruh Pertumbuhan Penjualan, Profitabilitas, Struktur Aktiva dan Ukuran Perusahaan Terhadap Struktur Modal Pada Perusahaan Pariwisata dan Perhotelan di BEI. E-Jurnal Manajemen Universitas Udayana, 3(7), 2050-2065.

Rodoni, Ahmad \& Herni Ali. 2014. Manajemen Keuangan Modern. Jakarta: Mitra Wacana Media.

Sinaga, Poltak. 2014. Manajemen Keuangan Teori dan Aplikasi. Medan : CV. Mitra.

Sitanggang, J.P. 2013. Manajemen Keuangan Perusahaan Lanjutan. Jakarta: Mitra Wacana Media.

Siti Nurlaela, S. A. M. D. (2017). Pengaruh Ukuran Perusahaan, Pertumbuhan Asset, Profitabilitas Dan Pertumbuhan Penjualan Terhadap Struktur Modal Perusahaan Cosmetics and Household Di Bursa Efek Indonesia. Jurnal Akuntansi Dan Pajak, 18(01), 16-30.

Sudana, I Made. 2011.Manajemen Keuangan Perusahaan Teori \& Praktik. Jakarta: Erlangga.

Sunyoto, Danang. 2013. Metodologi Penelitian Akuntansi. Cetakan Pertama. Yogyakarta: CAPS.

Suweta, N. M. N. P. D., \& Dewi, M. R. (2016). Pengaruh Pertumbuhan Perjualan, Struktur Aktiva, dan Pertumbuhan Aktiva Terhadap Struktur Modal. E-Jurnal Manajemen Unud, 5(8), 5172-5199.

Syahyunan. 2013. Manajemen Keuangan 1. Edisi Kedua. Medan : USU Press.

Watung, A. K. S., S.Saerang, I., \& Tasik, H. H. D. (2016). Aktiva Terhadap Struktur Modal Industri Barang Konsumsi Di Bursa Efek Indonesia. Jurnal EMBA, 4(2), 726-737.

Wira, Desmond. 2011. Analisis Fundamental Saham. Penerbit Exceed. 